\title{
BAND-PASS FILTER CIRCUIT DESIGN FOR MULTI-FREQUENCY ELECTRICAL IMPEDANCE TOMOGRAPHY SYSTEM
}

\author{
Ayu Jati Puspitasari ${ }^{1}$ and Endarko ${ }^{2}$ \\ 1) Elektronika Instrumentasi, Jurusan Teknofisika Nuklir, STTN-BATAN, Yogyakarta, \\ Indonesia, ayu.puspitasari@batan.go.id \\ 2) Departemen Fisika, Fakultas Sains, Institut Teknologi Sepuluh Nopember (ITS), \\ Surabaya, Indonesia, endarko@gmail.com
}

\begin{abstract}
ABSTRAK
RANCANGBANGUN RANGKAIAN BAND-PASS FILTER UNTUK SISTEM MULTIFREQUENCY ELECTRICAL IMPEDANCE TOMOGRAPHY. Electrical Impedance Tomography (EIT) adalah salah satu teknologi pencitraan yang sedang berkembang saat ini. Prinsip dari sistem EIT adalah penginjeksian arus listrik pada objek yang memiliki impedansi dan pengukuran tegangan melalui susunan elektroda. Sumber arus yang presisi, stabil, dan ber-bandwidth lebar dibutuhkan untuk mendapatkan pengukuran tegangan yang akurat. Sumber arus yang digunakan pada sistem EIT ini adalah VoltageControlled Current Source (VCCS). Blok rangkaian VCCS ini terdiri dari beberapa rangkaian, salah satunya adalah rangkaian filter. Rangkaian filter yang cocok untuk sistem EIT multi-frequency adalah bandpass filter. Penelitian ini telah merancang dan membangun sebuah rangkaian band-pass filter dengan frekuensi cut-off 1 dan $250 \mathrm{kHz}$, koefisien Butterworth, unity gain, dan topologi Sallen-Key.
\end{abstract}

Kata kunci: band-pass filter, frekuensi cut-off, multi-frequency electrical impedance tomography

\begin{abstract}
BAND-PASS FILTER CIRCUIT DESIGN FOR MULTI-FREQUENCY ELECTRICAL IMPEDANCE TOMOGRAPHY SYSTEM. Electrical Impedance Tomography (EIT) is one of the emerging imaging technologies recently. The principle of the EIT system is to inject electric current into an impedance object and measure the voltage based on the electrodes array. The current source that precise, stable, and wide-bandwidth is required to obtain voltage measurements accurately. The current source used for this EIT system is Voltage-Controlled Current Source (VCCS). The VCCS block circuit consists of several circuits, one of them is a filter circuit. The suitable filter for the multi-frequency EIT system is the band-pass filter. This research has been designed and fabricated a band-pass filter with cut-off frequency 1 and $250 \mathrm{kHz}$, which is using the Butterworth coefficient, unity gain, and Sallen-Key topology.
\end{abstract}

Keywords: band-pass filter, cut-off frequency, multi-frequency electrical impedance tomography

\section{BACKGROUND}

Electrical impedance tomography (EIT) is categorized as cheaper, non-invasive and non-harmful imaging technology. The EIT technique's principle is the imaging of the electrical resistivity distribution of an object. EIT can be applied in various fields, such as medical, industry, and geophysics [1].

In the medical field, the EIT utilizes a weak electric current (in the milliampere) to be injected into the human body [2]. The electric current is applied to the surface of the body using electrodes, then the surface voltage will be measured and used to reconstruct the image. EIT measurement depends on the electrical properties of human body tissues or phantom materials [1]. EIT can differentiate body tissue types based on different impedance values. At certain frequencies, there is a big difference between the impedance of the organ and the object [2]. 
It hangs on various methods to get a good image quality. It is important to improve the hardware system to get accurate voltage measurement data. Moreover, the quality of image reconstruction depends on the voltage data and reconstruction algorithm [3]. The current source has an important role to generate accurate voltage data. Stable, precision and wide bandwidth current source will produce accurate voltage data, so the system can generate a good image $[4,5]$.

The current source used in the EIT system is the Voltage-Controlled Current Source (VCCS). The EIT current injection requires $1 \mathrm{~mA}$ that has a frequency above 10 $\mathrm{kHz}$. The current source must be capable of supporting loads from $100 \Omega$ to $10 \mathrm{k} \Omega[3,6]$. The VCCS circuit block consists of four circuits: Voltage-Controlled Oscillator (VCO), filter, amplifier, and Voltage-to Current Converter (VCC) [3]. This research will focus on the band-pass filter circuit for the Multifrequency EIT system.

The filter circuit is used to pass signals with certain frequencies and attenuate the others. One of the filter type is a band-pass filter. Band-pass filter (BPF) is a filter used to pass a signal between 2 cut-off frequencies [7].

The quality of the filter can be determined from the filter order (Fig. 1) and the quality factor $(\mathrm{Q})$. To achieve a higherorder, there is a cascade that used to design. Filter design is based on the first and second orders which can be arranged in series, according to the desired order as in Fig. 2.

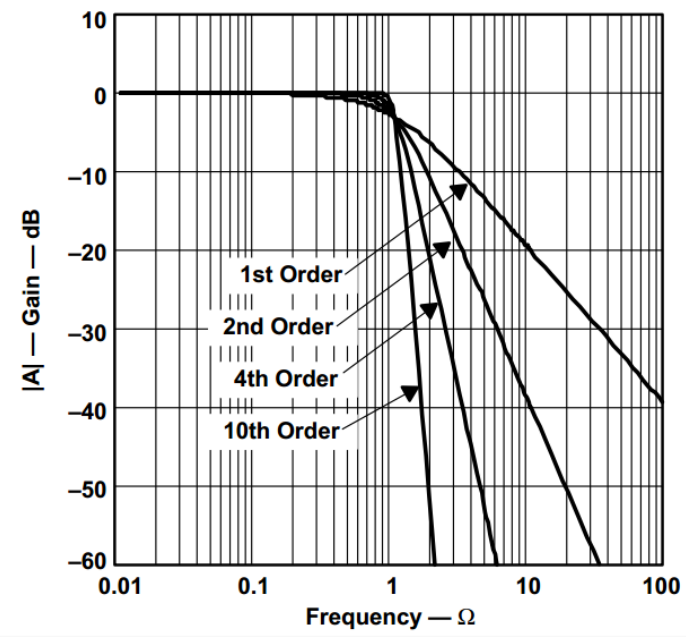

Figure. 1. Filter order comparison [8]

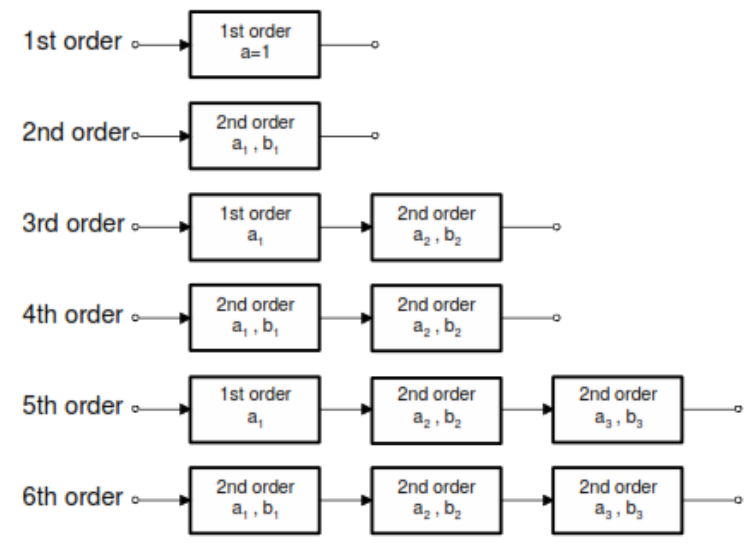

Figure. 2. Cascading filter stages for higher-order filters [8]

Quality factor (Q) is equivalent to filter order. The Q and pass-band width are contrary. Regarding quality factor $(\mathrm{Q})$, there are two kinds of filter topology design. They are Sallen-Key and Multiple Feedback (MFB) topology. Sallen-Key topology is usually applied to unity gain $(\mathrm{A}=1)$ and low $\mathrm{Q}(\mathrm{Q}<3)$. While MFB is usually used on a filter that requires high $\mathrm{Q}$ and gain.

In addition, there are three types of coefficients commonly used in designing filters such as Butterworth, Tchebyscheff, and Bessel (Fig. 3) [8]. The selection of filter coefficients can be customized by system requirements.

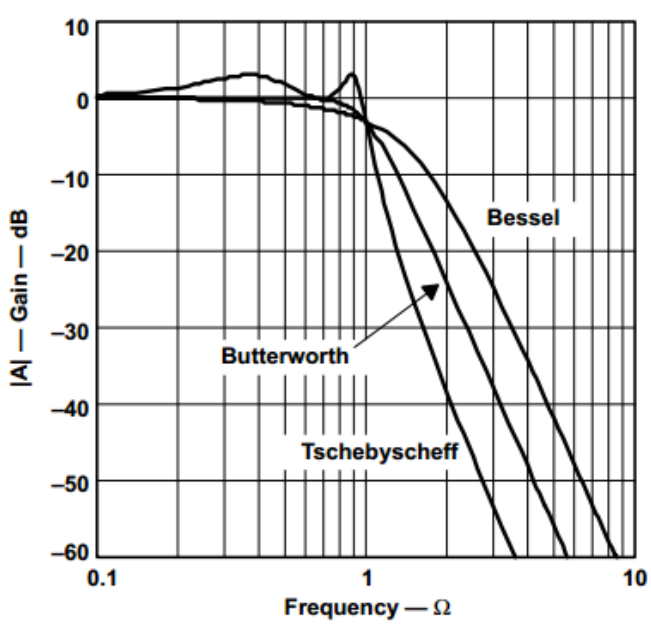

Figure. 3. Comparison of Gain Responses in Different Filter Coefficient [8]

In this Multi-frequency EIT (MFEIT) system, a band-pass filter is required. The MFEIT system requires a flat pass-band, so the Butterworth coefficient is chosen. The simplest 
design of the band-pass filter is a low-pass filter and a high-pass filter connected in series. This BPF design is usually applied to a filter that requires a wide pass-bandwidth. For example, a 1st order low-pass filter and a 1st order high-pass filter will generate a 2nd order band-pass filter. Therefore, a 2nd order lowpass filter (Fig. 4) and a 2nd order high-pass filter (Fig. 5) associated with a 4th order bandpass filter [8].

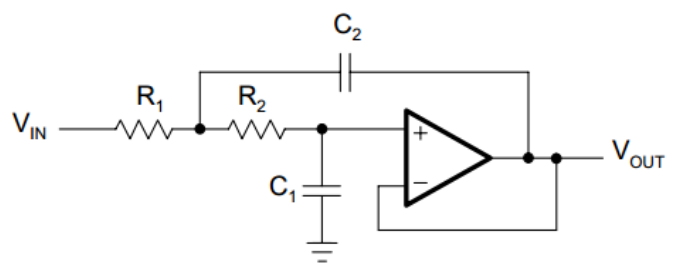

Figure. 4. 2nd order unity-gain Butterworth low-pass filter with SallenKey topology [8]

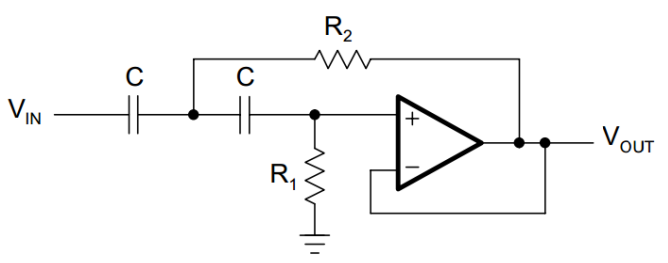

Figure. 5. 2nd order unity-gain Butterworth high-pass filter with SallenKey topology [8]

The aim of this research is to design the band-pass filter circuit for multi-frequency EIT, which is able to pass a signal with frequency 1 to $250 \mathrm{kHz}$. Other parameters are 4th order, Sallen-key topology and Butterworth coefficient.

\section{METHODS}

\section{Design of Band-Pass Filter}

The band-pass filter (BPF) circuit in this system is to pass the signal in frequency between $1 \mathrm{kHz}$ to $250 \mathrm{kHz}$ with 4th order, Butterworth coefficient, Sallen Key topology and unity gain. Basically, the BPF is a lowpass filter (LPF) and a high-pass filter (HPF) in series connection. For LPF (Fig. 4), the circuit uses resistor and capacitor values according to equations (1) and (2) [8].

$$
\begin{gathered}
C_{2} \geq C_{1} \frac{4 b_{1}}{a_{1}^{2}} \\
R_{1,2}=\frac{a_{1} C_{2} \mp \sqrt{a_{1}^{2} C_{2}^{2}-4 b_{1} C_{1} C_{2}}}{4 \pi f_{c} C_{1} C_{2}}
\end{gathered}
$$

For the HPF circuit (Fig. 5), the circuit uses resistor and capacitor values based on equations (3) and (4), with the Butterworth constant $\mathrm{a}_{1}=1.4142$ and $\mathrm{b}_{1}=1$ [8].

$$
\begin{aligned}
& R_{1}=\frac{1}{\pi f_{c} C a_{1}} \\
& R_{2}=\frac{1}{4 \pi f_{c} C b_{1}}
\end{aligned}
$$

\section{Simulation of Design Band-Pass Filter}

Before filter fabricating, the designed filter is simulated using Orcad PSpice 9.2. The designed filter is simulated in the frequency range $100 \mathrm{~Hz}$ to $1 \mathrm{MHz}$ to know the Bode magnitude or gain plot $(\mathrm{dB})$.

\section{Band-Pass Filter Test}

BPF circuit test is done using a signal generator and an oscilloscope as Fig. 6 .

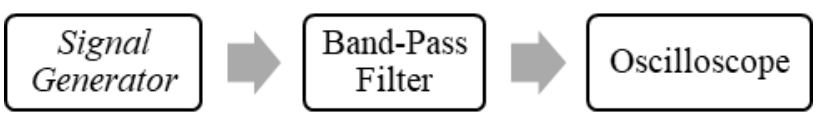

Figure. 6. Test scheme of a band-pass filter

\section{RESULT AND DISCUSSION}

\section{Circuit Design}

Designed BPF circuit based on is shown in Fig. 7. This circuit uses two LF412 op-amps, resistors, and capacitors based on Eq. (1) to (4). The resistors and capacitors value in Fig. 7 has beena rounded and adjusted to the component value on the market. 


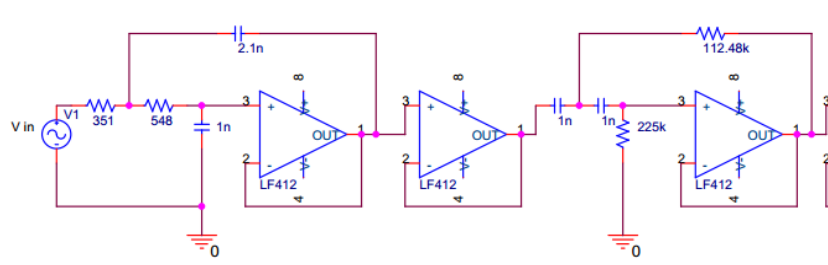

Figure. 7. 4th order unity-gain Butterworth band-pass filter with Sallen-Key topology

The addition of the unity-gain buffer circuit in each part of the filter has the function to support the current at high frequencies and loads.

\section{Designed Circuit Simulation}

Before fabricating, the designed circuits have been simulated using Orcad PSpice 9.2. This band-pass filter was designed based on 2 circuits, each circuit was simulated to find out the voltage response to frequencies. The simulation is shown in Fig. 8 to 10.

Fig. 8 shows that the signal has a $-3 \mathrm{~dB}$ gain when the frequency is $247.485 \mathrm{kHz}$. It means that the designed low-pass filter is capable of passing signals with a frequency less than $247.485 \mathrm{kHz}$ or about $250 \mathrm{kHz}$.

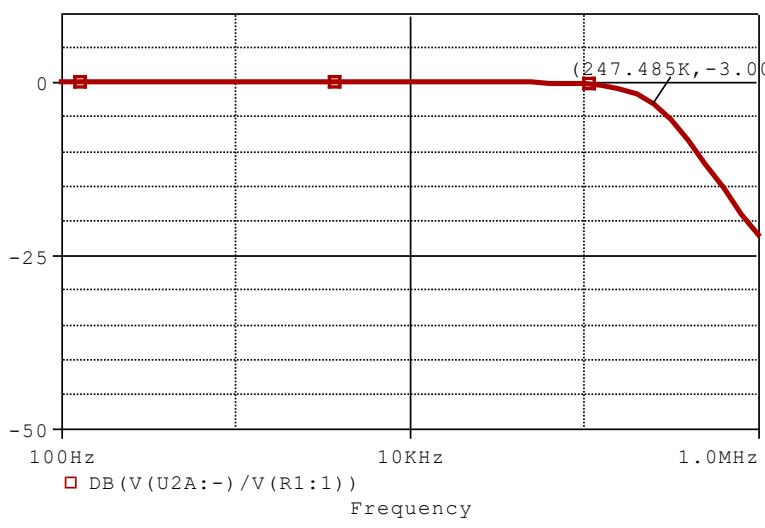

Figure. 8. Low-pass filter simulation

It is also shown in Fig. 9 for the designed high-pass filter simulation result. It is able to pass signals with frequency greater than $992.504 \mathrm{~Hz}$ or about $1 \mathrm{kHz}$.

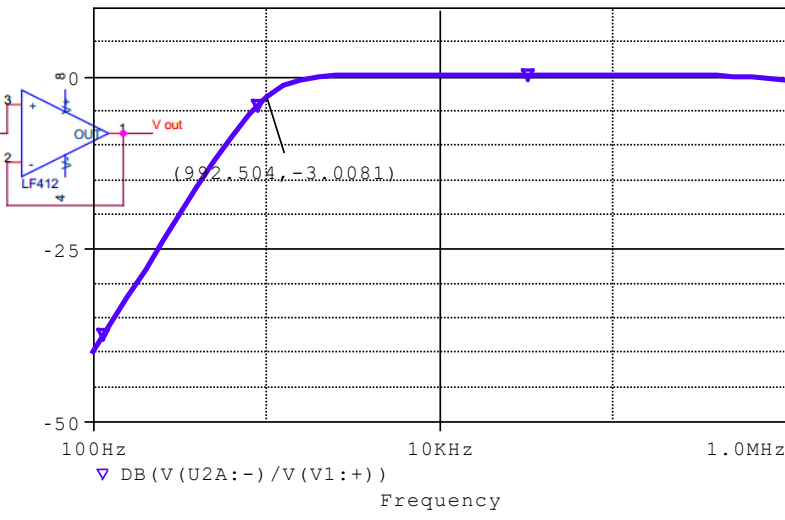

Figure. 9. High-pass filter simulation

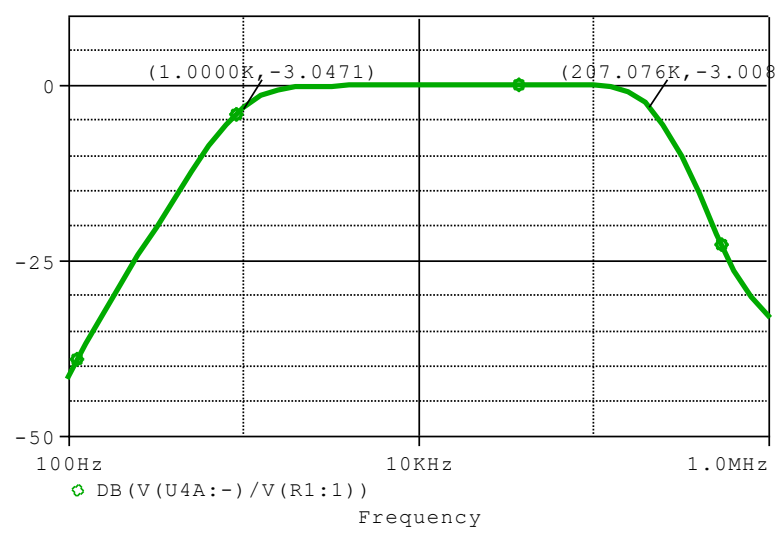

Figure. 10. Band-pass filter simulation

On the other hand, the low-pass and high-pass filter have distinctive when connected as a band-pass filter. The result in Fig. 10 shows the filter is capable of passing a signal with frequency between $1 \mathrm{kHz}$ to about $207 \mathrm{kHz}$. The difference between simulation results and expectation value is $0 \%$ for $\mathrm{fc}_{1}$ (low cut-off frequency) and $17.2 \%$ for $\mathrm{fc}_{2}$ (high cutoff frequency).

\section{Fabricated Band-Pass Filter Test}

BPF circuit test is done as Fig. 11. The signal generator is settled into $4 \mathrm{~V}_{\mathrm{p}-\mathrm{p}}$ and varied from $1 \mathrm{~Hz}$ to $1 \mathrm{MHz}$. Then it plotted signal gain $(\mathrm{dB})$ by frequencies $(\mathrm{Hz})$.

The $0 \mathrm{~dB}$ gain means that the output signal is equal to the input signal, in other words, the signal is passed. Moreover, the gain less than $0 \mathrm{~dB}$ means that there is signal attenuation, from the Fig.11, the attenuation occurs for frequency less than $1 \mathrm{kHz}$ and more than $250 \mathrm{kHz}$.

Fig. 11 shows that the gain signal is -3 $\mathrm{dB}$ for frequency $1 \mathrm{kHz}$ and $250 \mathrm{kHz}$. So it means that the fabricated BPF in this study can 
pass the signal with a frequency between 1 and $250 \mathrm{kHz}$.

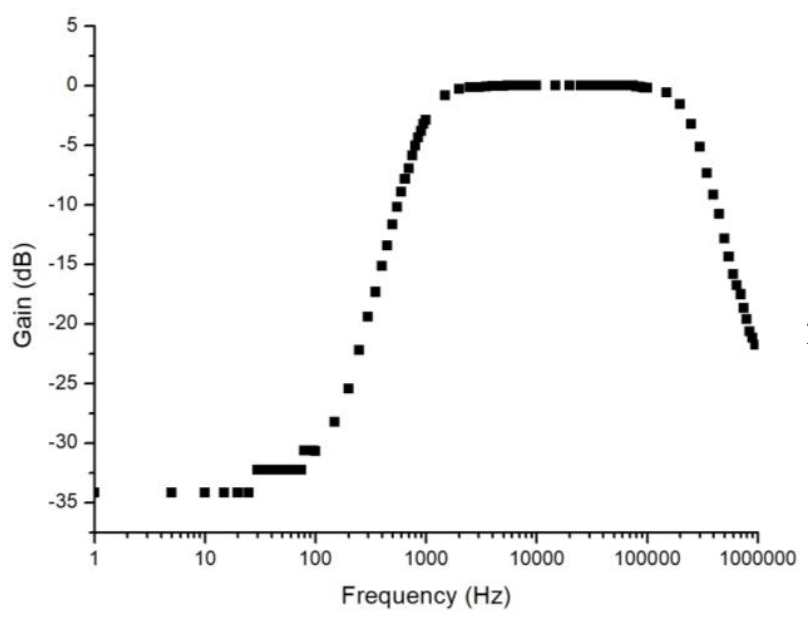

Figure. 11. Designed BPF test result

The test graph (Fig.11) is corresponding with the Butterworth graph and the 4th order graph slope. In addition, it shows that there is no ripple or gain. This is in accordance into the expectation that the filter is unity gain.

In order to test results in accordance with expectation or calculation, the value of the resistor and the capacitor should be thorough with the calculation. It is important to pay attention to the tolerance value of the resistor and capacitor components. The smaller tolerance value, the less error will be generated.

There is a difference in the cut-off frequency between fabrication and simulation. The difference is $2.5 \%$ for $\mathrm{fc}_{1}$ and $17.2 \%$ for $\mathrm{fc}_{2}$. However, the cut-off frequency of the fabrication circuit and expectation value have better results. The difference between these two values is $2.5 \%$ for $\mathrm{fc}_{1}$ and $0 \%$ for $\mathrm{fc}_{2}$.

\section{CONCLUSIONS}

The band-pass filter can be fabricated from the low-pass filter and high-pass filter that connected in series. The designed bandpass filter is able to pass signals with frequencies between 1 to $250 \mathrm{kHz}$ that has been proven through simulation and real testing. So, this designed band-pass filter is suitable for multi-frequency EIT system on medical purpose.

\section{REFERENCES}

1. V. Sarode, P. M. Chimurkar, and A. N. Cheeran, "ELECTRICAL IMPEDANCE TOMOGRAPHY (EIT) BASED MEDICAL IMAGING USING FINITE ELEMENT METHOD (FEM)," Int. J. Eng. Sci. Emerg. Technol., vol. 1, no. 2, pp. 83-89, Feb. 2012.

2. Z. Shuai, X. Guizhi, G. Duyan, and Y. Weili, "Multi-frequency EIT Hardware System Based on DSP," Eng. Med. Biol. Soc. 2006 EMBS 06 28th Annu. Int. Conf. IEEE, vol. Supplement, pp. 6677-6680, 2006.

3. M. Khalighi, B. V. Vahdat, M. Mortazavi, and M. Mikaeili, "Design and Implementation of Precise Hardware For Electrical Impedance Tomography (EIT)," IJST Trans. Electr. Eng., vol. 38, no. E1, pp. 1-20, 2014.

4. T. R. Qureshi, C. R. Chatwin, and W. Wang, "Design of Wideband Voltage Source Having Low Output Impedance, Flexible Gain and Controllable Feedback Current for EIT Systems," 2012 2nd Int. Conf. Biomed. Eng. Technol., vol. 34, pp. 45-50, 2012.

5. Z. Li, Z. Xu, C. Ren, W. Wang, D. Zhao, and H. Zhang, "Study of Voltage Control Current Source in Electrical Impedance Tomography System," 2010 4th Int. Conf. Bioinforma. Biomed. Eng. ICBBE, pp. 1-4, 2010.

6. S. M. M. Islam, M. A. R. Reza, and M. A. Kiber, "Performances of Multi-Frequency Voltage to Current Converters for Bioimpedance.

7. D. L. Terrell, Op Amps: Design, Applications, and Troubleshooting. Newnes, 1996.

8. R. Mancini, Op Amps for Everyone. Texas: Texas Instruments Incorporated, 2002. 
Jurnal Forum Nuklir (JFN), Volume 7, Nomor 2, November 2013 